DOI: $10.25178 /$ nit.2018.3.5

\section{ГИДРОНИМЫ ТУВЫ: ТЮРКСКИЕ, МОНГОЛЬСКИЕ, САМОДИЙСКИЕ}

\section{Андрей Д. Каксин}

Хакасский государственный университет

им. Н. Ф. Катанова,

Российская Федерация

\section{WATER-NAMES OF TUVA: TURKIC, MONGOLIAN, SAMOYED}

В статье рассматривается несколько пластов древних гидронимов Тувы, а именно те названия рек и озер, этимология которых может быть возведена к тюркским, монгольским или самодийским корням. Наличие последних объясняется ранним приходом на эту территорию предков самодийских народов. В течение последующих тысячелетий самодийский след в очень сильной степени был стерт: данные самодийцами названия были пересмотрены сначала монгольскими народами, а затем - тюркскими.

Основой такого рассмотрения (т.е. сближения тюркских и монгольских языков) является алтайская теория, одним из главных постулатов которой является утверждение о существовании одного праязыка. От этого единого корня вначале было несколько ответвлений, от которых, далее, произошли современные тюркские, монгольские, тунгусо-маньчжурские, японский и корейский языки. Современное тюркское звучание и унифицированная на картах тюркско-русская (или монгольскорусская) форма считаются самыми поздними (u, видимо, окончательными) вариантами зародившихся в древности гидронимов.
Andrey D. Kaksin

N. F. Katanov Khakass State University, Russian Federation

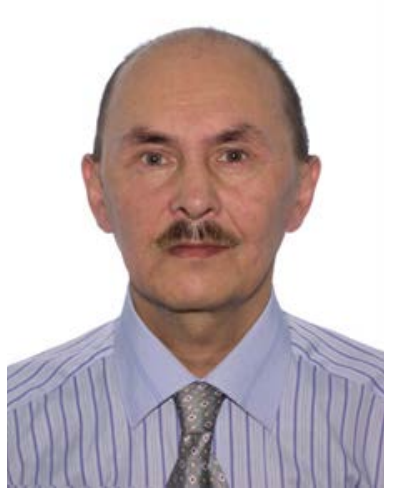

The article covers several layers of ancient hydronyms of Tuva, especially those names of the rivers and lakes which etymologically can be of Turkic, Mongolian or Samoyed origin. The presence of the latter on the list can be explained by early arrival of ancestors of the Samoyed people to the territory of Tuva. During the next millennia, the Samoyed trace in the local toponymy was almost completely erased: the place names initially given by Samoyeds were revised first by the Mongolian people, and then by the Turks.

The reason for viewing toponymical history of Tuva in such a way (i.e. through the lens of convergence of Turkic and Mongolian languages) is the Altai theory, one of the main points whereof is the notion of one parent language for both. This root language later produced several offshoots, wherefrom modern Turkic, Mongolian, TungManchurian, Japanese and Korean languages developed. Contemporary Turkic pronunciation and the Turkic-Russian (also called Mongolian-Russian) form presented in its unified shape on geographical maps can be considered as the latest (and, probably, final) variants of the hydronyms which originally appeared in ancient times.

Каксин Андрей Данилович - доктор филологических наук, ведущий научный сотрудник Института гуманитарных исследований и саяно-алтайской тюркологии Хакасского государственного университета им. Н. Ф. Катанова. Адрес: 655017, Россия, г. Абакан, ул. Ленина, д. 94, а/я 14. Тел.: +7 (3902) 223494. Эл. адрес: adkaksin@yandex.ru

Kaksin Andrey Danilovich, Doctor of Philology, Leading researcher, Institute of Humanitarian Research and Sayan-Altai Turkology, N. F. Katanov Khakass State University. Postal address: P/b 14, 92, Lenin St., 655017, Abakan, Russia. Tel.: +7 (3902) 223494. E-mail: adkaksin@yandex.ru 
Ключевые слова: Тува; топоним; топонимика Тувы; гидроним; самодийский язык; алтайская языковая семья; самодийцы; тюркский язык; монгольский язык; алтайская теория
Keywords: Tuva; place name; Tuvan toponymy; hydronym; Samoyed language; Altai language family; Samodians; Turkic languages, Mongolian languages; Altai theory

\section{Введение}

В современной лингвистике возрастает актуальность исследования топонимии с позиций разных направлений, в т. ч. двух значимых в случае с языками коренных народов - учения о репрезентации языковой картины мира и когнитивного. Именно с позиций когнитивистики мы подошли к анализу гидронимов (названий рек и озер) Тувы.

Основное наше предположение сводится к тому, что в основе большинства древних названий водоемов Тувы лежит яркое и точное определение (эпитет); и лишь некоторые гидронимы имеет смысл трактовать как образования, в основе которых лежит метафоризация.

Следует сказать, что материал, к которому мы обращаемся, в достаточной степени систематизирован и описан: по данной теме опубликованы работы А. П. Дульзона, Б. И. Татаринцева, Б. К. Ондар и других специалистов (Дульзон, 1959, 1971; Кызласов, 1959; Боргояков, 1970, 1973; Татаринцев, 1976, 1993; Молчанова, 1979; Розен, Малолетко, 1986; Матвеев, 1989, 1995, 2008; Ондар, 1995, 2004; Бутанаев, 1995, 1999; Мурзаев, 1996; Сунчугашев, 2005, 2009; Бурыкин, 2011; Монгуш, 2016: Электр. ресурс; Виноградов, 2017; Дамбуев, 2017; Кичикова, Манджиева, Супрун, 2017).

Топонимическая система Тувы - многослойная, сформировалась в результате смены друг другом языков трех семей: енисейской, уральской, алтайской. Говоря иначе, названия рекам и озерам последовательно давали носители енисейских, самодийских, монгольских и тюркских языков.

\section{О смене языковых семей на территории Южной Сибири}

Названия на -дат, -тет, -ул, -кан (Кызласов, 1959: 75), ограниченно обнаруживаемые на этой территории, подтверждают гипотезу о енисейцах как первых, самых древних насельниках региона. Их сменили самодийцы, самодийцев - монголы, но в языке пришедших последними и утвердившихся здесь тюркских племен часть древних названий сохранилась.

«На территории Сибири тюркоязычные народности появились сравнительно поздно, - пишет М. И. Черемисина. - Вероятно, этот процесс начался не- 
задолго (примерно за два столетия) до начала нашей эры. Историки предполагают, что тюркскую речь принесли сюда гунны, появление которых в Сибири датируется III в. до н. э.» (Черемисина, 1992: 11).

Считаем, что, только придерживаясь традиционного, компаративистского, мнения по поводу единства алтайской семьи, можно привести в систему все новые данные по алтайской языковой семье (результаты последних лингвистических и археологических исследований) и комплексно обосновать точку зрения об удаленности прародины алтайских языков от Алтайских гор.

Понятно, что представление об алтайском языковом единстве зародилось не на пустом месте: слишком много общей лексики обнаружилось в рассматриваемых языках. Большое сходство наблюдается и в типологии рассматриваемых языков. Другими словами, алтайская теория остается незыблемой, но и в ее рамках мы придерживаемся того мнения, что алтайская прародина находилась достаточно далеко от гор Алтая, а «пратюркский элемент» недолго находился в составе алтайского единства. Здесь можно сослаться и на результаты последних исследований вопроса о тюркских прародинах. Эти результаты, на наш взгляд, говорят в пользу той точки зрения, что пратюркский язык отделился уже на первых этапах развития алтайской семьи (и «переместился» во Внутреннюю Монголию, на Ордос). Спустя тысячелетия тюркские и монгольские языки вновь «встретились» на Саяно-Алтайском нагорье, но до этого монгольские языки, распространившиеся там ранее, уже успели вступить в контакт с енисейскими и самодийскими языками.

Сравнивая гипотетическое развертывание в пространстве двух языковых семей (уральской и алтайской), для уральских языков можно констатировать параллельное (сбалансированное, равномерное, почти в едином ритме) развитие двух частей («крыльев»). Когда единая семья распалась, одна из частей «сдвинулась» в сторону невысоких в этом месте Уральских гор, т. е. в сторону Европы. Впоследствии она разделилась на три потока: 1) в бассейн Печоры и оттуда - на запад (саамы); 2) в бассейн Камы и далее (прибалтийско-финская, финно-волжская, финно-пермская ветви); 3) на юго-запад, а затем в разных направлениях - на запад (венгры), на север (манси) и северо-восток (ханты). Вторая «половина», самодийская, двигавшаяся в юго-восточном направлении, заняла бассейн Средней Оби с ее притоками, Северный Алтай, Присаянье; лишь потом началось движение самодийцев на север (Хелимский, 1996: 101-102).

Алтайская семья, очевидно, имела прародиной довольно большую территорию к югу от Байкала, включая окрестности оз. Хубсугул и бассейн Верхней Селенги. Затем, до оформления твердого, устойчивого языкового единства, от этой территории (на которой остались монголы) поочередно отошли тюрки, предки корейцев и японцев и тунгусы-маньчжуры. Началось их отдельное, независимое друг от друга развитие. Но впоследствии тюрки и монголы, недалеко от общей прародины, встретились снова. Но, как известно, до этой встречи 
тюрков и монгол в Присаянье, монголы, пришедшие туда раньше, уже успели вступить в контакты с самодийцами и енисейскими народами. Отсюда и многочисленные перекрестные заимствования во всех названных языках, а также те гидронимы (или их элементы), выяснением семантики которых мы занимались. Древние гидронимы, на наш взгляд, одними из первых должны быть привлечены для доказательства алтайской теории. Кроме того, предполагая даже не вероятность, а неизбежность значительных семантических расхождений, нужно искать новые слова в корейском и японском языках, которые могли бы помочь реконструкции древней праалтайской системы.

Топонимия (и особенно - гидронимия) Тувы дает очень ценный материал для сравнительно-исторических исследований, а результаты, полученные компаративистами, во многих случаях помогают правильной этимологизации древних названий. Речь идет, в первую очередь, о тех гидронимах (преимущественно - названиях рек), которые остались в результате длительного проживания здесь носителей самодийских языков. До широкого распространения на этой территории тюркских наречий здесь были распространены преимущественно южно-самодийские языки.

О времени и обстоятельствах прихода самодийцев (и только потом - тюрков) на территорию Южной Сибири известно уже достаточно много. И не только среди археологов и историков, но и компаративистов тоже. Вот как об этом пишет Е. А. Хелимский:

«Продвинувшись на восток до Енисея, самодийцы застали здесь тунгусоязычное население, от которого и заимствовали название этой реки... Определенное культурное влияние оказали на самодийцев и тюрки, которые в последние века I тыс. до н. э. продвинулись в северную часть Алтайского нагорья и на юг западносибирской тайги. ... Совокупность лингвистических данных позволяет предположительно локализовать позднюю самодийскую прародину (накануне распада праязыкового единства) в районе Чулыма Среднего Енисея» (Хелимский, 1996: 102).

Очевидно, что все рассмотренные названия достаточно легко интерпретируются как производные от первоначальных корней (указывающих на местоположение реки, ее «характер», свойства ее берегов, значимые признаки окружающей местности). Поэтому в большинстве случаев при поиске исходного, мотивирующего слова исследователи ориентируются на базовый словарь языковой семьи (в нашем случае - алтайской). Подчеркнем, что основой нашего подхода является алтайская теория, одним из главных постулатов которой является утверждение о существовании одного праязыка - алтайского (бытовавшего, впрочем, достаточно далеко от Алтая). От этого единого корня вначале было несколько ответвлений, от которых далее - произошли современные тюркские, монгольские, тунгусо-маньчжурские, японский и корейский языки. Для доказательства алтайского родства компаративисты используют не только 
лексические данные, напр., слова корейского языка kädzim, tsari, tsom, tsul, tabal и др. (Songmoo Kho, 1977), но и сведения о грамматических показателях.

По мнению А. В. Дыбо, «использование японского и корейского лексического материала при сопоставлении алтайских языков значительно повысило его надежность, уменьшая вероятность объяснения лексических совпадений ранними контактами. Таким образом, главная задача, стоящая перед современной алтаистикой, - построение максимально полной концепции алтайского праязыка и последующего развития и взаимоотношений алтайских языков путем последовательного, глубокого и строгого применения методик сравнительноисторического языкознания» (Дыбо, 2017: 752).

\section{О происхождении больиинства гидронимов Тувы}

По происхождению гидронимы Тувы разделяются на несколько групп, и в первую из них попадают, безусловно, тюркские.

Это, к примеру:

- названия рек: Агыш, Адыр-Бут, Ажык, Азөөт, Айлыг, Айлыгбай, Ак, Ак-Адыр, Ак-Белдир, Ак-Кара-Суг, Ак-Ой, Ак-Оюк, Ак-Сояк, Ак-Суг, Ак-Тал, Алгый-Ак, Алдыы-Ак-Адыр, Алдыы-Бугаш, Алдыы-Демирлиг, Амыл, АнааСуг, Анай-Ооруг, Аныяк-Кадыр-өөс, Аныяк-Ооруг, Арага-Төктүр, Ара-Сай, Арбык, Арга-Суг, Арга-Чарык, Арт-Аксы, Арыскан, Арыскан-Адыр, Атпак-Аксы, Ачылыг, Аялыг, Бай-Белдир, Байлаңныг-Үзүк, Бай-Сөөт, Бай-Хаак, Барлык, Башкы-Адыр;

- названия озер: Адыр-Шиви, Айбы-Хөл, Айлыг-Ары-Хөл, Ак-Аъттыг-Хөл, Ак-Даштыг-Хөл, Алагалыг-Хөл, Алгый-Хөл, Аскыр-Хөл, Бай- Хөл, Башкы-Хөл.

Ожидаемо много на карте Тувы монгольских названий рек и озер: АржаанХем, Ары-Булак, Ары-Ой, Ары-Хем, Аспаты, Аян-Хем, Аяңгаты, Бавыыдай, Бала, Балгазын, Барык, Хөндергей и др.; Бага-Нур, Шара-Нур и др.

Тюрко-монгольские (смешанные) названия рек и озер составляют отдельную группу: Ажыг-Ай-Хем, Ак-Баш-Хем, Ак-Боор, Ак-Бүрен, Ала-Суг, Алаш, Алдыы-Ак-Хем, Алдыы-Алама, Алдыы-Баш-Тайга-Хем, Алдыы-Божалыг, Алдыы-Дылаан-Кара, Алдыы-Ишкин, Алдыы-Каңгылыг, Амырак, Анаа-Хем, Аныяк-Хаактыг-Хем, Аныяк-Хем, Аныяк-Чыргакы, Аң-Адыр, Ара-Ой, АргадаХем, Арга-Олут-Хем, Арга-Хем, Ары-Торгалыг, Арыскан-Хем, Аът-Баштыг-Хем, Багай-Бестиг, Бадар-өөс, Бак-Төш-Хем, Бак-Чадыг, Бак-Чыттыг, Балгазын-Суг, Балдырган, Балчырганак, Балыктыг-Хем, Барыын-Ирелиг, Барыын-Мөөн, Барыын-Теректиг-Хем и др.; Алдыы-Дээрлиг-Хөл, Амдайгын-Хөл, Аңныг-Хөл, Ара-Ногаан-Хөл, Арга-Хөл, Ачыты-Хөл и др.

Естественно предположить, что после распада часть самодийцев продвинулась далее к югу, юго-востоку, и только после их утверждения в бассейне 
Верхнего Енисея туда пришли монголы. Именно этим обстоятельством можно объяснить наличие на этой территории самодийских по происхождению названий: Азас, Мынас, Талым, Ишкин, Ал-Шум и др.

На состоявшейся в июне 1958 г. научной конференции, посвященной 250-летию добровольного присоединения Хакасии к России, выдающийся археолог Л. Р. Кызласов выступил с докладом об этногенезе хакасов, в котором затронул и вопросы топонимики. Полагаем, что в ходе подготовки доклада он мог обсудить животрепещущую тему с А. П. Дульзоном, также принимавшим участие в этой конференции. Как бы то ни было, результатом размышлений Л. Р. Кызласова (об отражении в топонимике Хакасии истории заселения региона) явились следующие положения:

«Анализ топонимики Хакасско-Минусинской котловины и прилегающих к ней районов свидетельствует о том, что наряду с наслоившимися тюркскими топонимами более позднего происхождения здесь в основном господствовали топонимы, разъясняющиеся из угорских и самодийских языков. По-самодийски: “бю” (тазовские), “би” (энцы), “бу” (койбалы и маторы)“вода”. Этот термин носят следующие названия рек: Холба, Тайба, Колба, Салба (приток Убея), Карасиба, Тебе, Сейба, Буйба, Ирба, Туба, Салба (приток Кебежа), Анбу, Ерба (Чорба) и т. д. [Они] встречаются на единой территории, которая охватывает целиком Восточные Саяны (от р. Оки на востоке и до Енисея на западе), часть Западно-Саянского хребта, где они заходят на левобережье Енисея» (Кызласов, 1959: 73-74).

Как видим, выдающемуся археологу и знатоку хакасского языка Л. Р. Кызласову удалось очень наглядно показать, что во всех перечисленных гидронимах сохранились отголоски звучания тех языков, которые исторически предшествовали тюркским языкам на указанной территории. Это были енисейские и уральские языки, и вполне целесообразно, этимологизируя названия, необъяснимые тюркскими корнями, использовать данные по исторически предшествовавшим языкам.

Мы, ознакомившись с этой предварительной таксономией материала, делаем далее определенные выводы по языковой принадлежности и мотивационной основе древних гидронимов Тувы. При этом мы с самого начала предполагаем, что они отражают культуру аборигенных этносов (во всех ее проявлениях). Важно, что проанализированный в данном аспекте материал можно далее интерпретировать в аспекте сохранности топонимов, служащих источником сведений о географии Южной Сибири, являющихся источником разнообразной информации о жизнедеятельности коренного населения региона. Но это общий посыл.

Более конкретно, лингвисту необходимо поискать в этимологии этих древних корней логико-семантический подтекст. Беря во внимание форму, можно 
отметить структурную прозрачность как характерный признак, объединяющий слова в этой компактной группе: односложный корень, к которому присоединяется компонент со значением ‘вода / река’. Далее можно анализировать и глубинную семантику. При этом естественно полагать, что некоторые топонимы представляют собой образования, в основе которых лежит метафоризация. Важно и то, что метафоризация проистекает от постоянного стремления человека к какой-либо деятельности.

Для нас (в данном случае) очевидно, что метафоризация - очень сложное явление, появляется на поздних стадиях развития сообщества, а на ранних этапах развития метафору вполне заменял эпитет. Для древних гидронимов это положение применимо в первую очередь. Поэтому, считаем, объяснение семантики корневого элемента можно поискать в базовом словаре языковой семьи.

Проверяя эту гипотезу, опираясь на работы компаративистов, словари языков самодийской группы, мы сочли возможным включить в число самодийских названий рек Тувы слова, заканчивающиеся на -ба (-бе, -бу, -бӓ, -бӱ), -ум (-ым, -uм) $u$-ac/-aш (-ec/-ew). При этом мы ориентируемся в основном на списки Сводеша ${ }^{1}$ с данными языков самодийской семьи (https://ru.wiktionary.org/wiki/): там значатся слова камасинского и селькупского языков (соотносимые с ненецкими, нганасанскими и энецкими единицами), которые были использованы в качестве первого компонента при номинации рек (или других водоемов). С большой долей вероятности можно предполагать, что исходный корень мог иметь, например, значение: ‘щель, проход’, ‘туман', ‘лед’, ‘быстрый’, ‘большой’, 'гнилой', 'грязный’, ‘прямой’, 'желтый’. Все они могли послужить основой при создании названий для рек Шом-Шум, Шевештиг-Хем, Кошпес, Кожай, Каажырба и других. Использование простых определений, эпитетов и (значительно реже) метафор можно считать наиболее распространенным способом создания названий географических объектов у древних народов.

Хотя спорных случаев в этимологической трактовке гидронимов Тувы предостаточно (и эти случаи исходят из невозможности объяснить тюркскими и монгольскими словами), несомненную обусловленность современных названий енисейскими или самодийскими корнями увидеть очень сложно. Но, исходя именно из этих примеров, стоит допустить глубокое (дальнее) проникновение древних самодийцев в бассейн верховьев Оби и, далее, Верхнего Енисея. Тогда становятся объяснимы многие гидронимы (названия рек), смысл которых не выводится из материала тюркских и монгольских языков.

Например:

Шыжыма - по всей вероятности, гидроним субстратного происхождения: самодийцы могли назвать реку по особенностям ее берегов, как будто по-

\footnotetext{
${ }^{1}$ Списки Сводеша (Swadesh list) - предложенный американским лингвистом М. Сводешем инструмент для оценки степени родства языков по устойчивости базового словаря.
} 
крытых золой, пеплом от костра. Ср.: «уголь, ?жар: *śüб’e > ф. sysi (syte-), с. čâđđâ, э. седb, сядb, м. седb, мр. шёч, х. söj, мс. sül'i, сам. н. tuś śēj 'горячий уголь' (tu 'огонь')» (Основы ..., 1974: 405).

Шурам-Хол - название озера, по предположению автора «Топонимического словаря Тувы» Б. К. Ондар, произошло «от глагола шураар (шура-) 'прыгать, скакать; набрасываться, накидываться’, хөл 'озеро’» (Ондар, 2004: 241). На наш взгляд, это слишком прямолинейная этимология. Более глубокую, отдаленную этимологию, видимо, нужно искать в уральском праязыке, от которого отложилась самодийская ветвь. Мы склонны видеть указание на пространственный ориентир:

«зад, задняя часть, задний: *perä > ф. perä, эс. pära, э. пря 'голова', 'вершина', ‘кончик’, м. пря 'голова', ‘верхняя часть', у. бер ‘зад’, ‘задний’, к. бӧр ‘зад’,

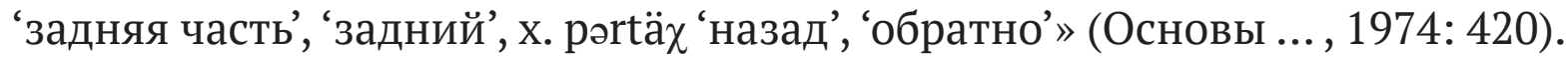

Как показывает наш опыт этимологизации гидронимов (по большей части названий рек, в меньшей степени - озер), главным признаком водоема, на который обращали внимание первые насельники, был пространственный: в каком месте находится водоем, как он видится людям в системе сложившихся пространственных ориентиров. На наш взгляд, именно особенности окружающего рельефа обусловили названия многих рек региона.

Анализ языкового материала позволяет понять, какие воззрения древних отразились в тех названиях, которые они дали окружающим их рекам, речушкам, озерам. Если анализировать корни искомых слов (во многих случаях второй элемент, действительно, воспринимается как апеллятив со значением 'вода / река'), достаточно легко приходит мысль о том, что они (эти корни) - суть определения или эпитеты, называющие ту или иную характерную особенность конкретной реки.

Источники происхождения топонимов на территории Тувы многообразны, но есть некоторые общие свойства (черты), характеризующие их. У каждого отдельно взятого наименования есть формальная и содержательная сторона, которые существуют в диалектическом единстве. Каждое из этих слов представляется двусоставным: есть постоянный семантический элемент со значением 'река', со свойственной ему формальной вариативностью (которая, в ряде случаев, проистекает из действия закона сингармонизма). Переменным является корень, он вариативен в семантическом смысле. Вариативность корня - более широкая, все же и она имеет свои рамки. Корень, являющийся определением или эпитетом, выбирается из круга слов, которые могут с какой-либо стороны характеризовать реку: обычно это слова типа 'короткая', ‘длинная', ‘мелкая’, ‘глубокая’, ‘каменистая’, ‘большая’, ‘маленькая’, ‘изогнутая’, ‘быстрая’, ‘рыбная’, 'медвежья', ‘лосиная’. 


\section{Заключение}

Таким образом, проведенное исследование актуально и в аспекте сравнительно-исторической этимологии, и когнитивистики (установления когнитивных моделей образования древних гидронимов). В последнее десятилетие лингвисты все чаще обращаются к проблемам ономастики с позиций работы человеческого сознания, в аспекте установления связей между разными видами речемыслительной деятельности. Такой анализ позволяет выяснить, как ономастические единицы отражают видение и восприятие мира человеком и способы его концептуализации в языке.

Топонимическая система рассматриваемой территории определенным образом связана со сменой господствовавших на ней языков. Опираясь на труды компаративистов, можно постулировать длительное «пребывание» на этой территории енисейских и самодийских языков, их длительный контакт с монгольскими языками, и только после этого - приход тюрков.

При дальнейшем, более детальном, исследовании материала, связанного с гидронимами, следует акцентировать вопросы истории тюркских и монгольских языков Южной Сибири. В частности, представляется целесообразным использовать, при уточнении этимологии ряда гидронимов, данные диалектологии (в отношении тувинского, тофаларского, хакасского и других тюркских языков региона). Небезынтересными будут разыскания по вопросу о возникновении смешанных, тюрко-монгольских, названий рек, озер, других водоемов. Результаты таких работ будут востребованы в компаративистике; в частности, они помогут при осмыслении сложных языковых процессов, протекавших в большом регионе Южной Сибири после распада алтайского праязыка.

\section{СПИСОК ЛИТЕРАТУРЫ}

Боргояков, М. И. (1970) К вопросу об этимологии гидронима «Молочный» // Советская тюркология. № 5. С. 85-87.

Боргояков, М. И. (1973) О происхождении названия Сора // Ученые записки Хакасского научно-исследовательского института языка, литературы и истории. Абакан : Хакасская областная типография. Вып. XVIII. С. 142-144.

Бутанаев, В. Я. (1995) Топонимический словарь Хакасско-Минусинского края. Абакан : Хакасский госуниверситет им. Н. Ф. Катанова. 268 с.

Бутанаев, В. Я. (1999) Хакасско-русский этнографический словарь. Абакан : Хакасский госуниверситет им. Н. Ф. Катанова. 237 с.

Бурыкин, А. А. (2011) Иноязычная ономастика русских документов XVIIXIX вв., относящихся к открытию и освоению Сибири и Дальнего Востока России, как исторический источник : дисс.... д-ра ист. н. СПб. 476 с. 
Виноградов, А. В. (2017) Гидронимы на мифологической основе // Научное обозрение. Биологические науки. № 3. С. 14-36.

Дамбуев, И. А. (2017) Топонимическое варьирование и вопросы нормализации топонимов в Республике Хакасия // Язык и культура. № 38. С. 23-40.

Дульзон, А. П. (1959) Тюрки Чулыма и их отношение к хакасам // Ученые записки Хакасского научно-исследовательского института языка, литературы и истории. Абакан : Хакасское книжное издательство. Вып. VII. С. 93-102.

Дульзон, А. П. (1971) Этнолингвистическая дифференциация тюрков Сибири // Структура и история тюркских языков / отв. ред. Э. В. Севортян. М. : Наука. 311 c. C. $198-208$.

Дыбо, А. В. (2017) Об этимологических параллелях в грамматике алтайских языков // Международный форум «Алтайская цивилизация и родственные народы алтайской языковой семьи» : сб. выступлений и статей, посвященных истории народов, имеющих общие алтайские историко-культурные и этногенетические корни (Бишкек, Чолпон-Ата, 20-22 июля 2017 г.) / отв. ред. К. Молдокасымов. Бишкек : Турар. 992 с. С. 751-761.

Кичикова, Н. А., Манджиева, Э. Б., Супрун, В. И. (2017) Топонимический словарь Республики Калмыкия. Элиста : ЗАОр «НПП «Джангар». 272 с.

Кызласов, Л. Р. (1959) К вопросу об этногенезе хакасов // Ученые записки Хакасского научно-исследовательского института языка, литературы и истории. Абакан : Хакасское книжное издательство. Вып. VII. С. 70-92.

Матвеев, А. К. (1989) Финно-угро-самодийская топонимия на территории СССР как объект лингвистического исследования // Вопросы финно-угорской ономастики / отв. ред. М. Г. Атаманов. Ижевск : Удмуртский институт истории, языка и литературы УрО АН СССР. 182 с. С. 5-18.

Матвеев, А. К. (1995) Апеллятивные заимствования и стратификация субстратных топонимов // Вопросы языкознания. № 2. С. 29-42.

Матвеев, А. К. (2008) Эволюционные процессы в ономастике // Вопросы ономастики. № 6. С. 130-136.

Молчанова, О. Т. (1979) Топонимический словарь Горного Алтая. Горно-Алтайск : Горно-Алтайское отделение Алтайского книжного издательства. 397 с.

Монгуш, А. А. (2016) О геологическом значении некоторых топонимов Тувы [Электронный ресурс] // Новые исследования Тувы. № 1. URL: https://nit.tuva. asia/nit/article/view/72 (дата обращения: 16.05.2018).

Мурзаев, Э. М. (1996) Тюркские географические названия. М. : Издательство восточной литературы. 253 с. 
Ондар, Б. К. (1995) Краткий словарь гидронимов Тувы / под ред. И. В. Кормушина. Кызыл : Тувинское книжное издательство. 48 с.

Ондар, Б. К. (2004) Топонимический словарь Тувы. Абакан : Издательство ХГУ им. Н. Ф. Катанова. 256 с.

Основы финно-угорского языкознания (1974) / отв. ред. В. И. Лыткин. М.: Наука. 484 с.

Розен, М. Ф., Малолетко, А. М. (1986) Географические термины Западной Сибири. Томск : Издательство Томского университета. 205 с.

Сунчугашев, Р. Д. (2005) Хакасские гидрографические термины // Ученые записки Хакасского научно-исследовательского института языка, литературы и истории. Абакан : Хакасское книжное издательство. Вып. XXII. С. 172-176.

Сунчугашев, Р. Д. (2009) Топонимия Хакасии / науч. ред. И. В. Кормушин. Абакан : Хакасское книжное издательство. 198 с.

Татаринцев, Б. И. (1976) Монгольское языковое влияние на тувинскую лексику. Кызыл : Тувинский научно-исследовательский институт языка, литературы и истории. 129 с.

Татаринцев, Б. И. (1993) О некоторых древних топонимах тюркского происхождения на территории Тувы // Вопросы тувинского языкознания / отв. ред. Д. А. Монгуш, Б. И. Татаринцев. Кызыл : Тувинский научно-исследовательский институт языка, литературы и истории. 128 с. С. 105-112.

Хелимский, Е. А. (1996) Очерк истории самодийских народов // Финно-угорский мир (Справочник по истории, культуре и языку) / отв. ред. Дьёрдь Нановски. Будапешт : Veszpremi. 192 с. С. 101-115.

Черемисина, М. И. (1992) Языки коренных народов Сибири : учебное пособие. Новосибирск: Новосибирский государственный университет. 92 с.

Songmoo, Kho (1977) On the contacts between Korean and the Turkic languages // Altaica: Proceeding of the 19th Annual Meeting of the Permanent International Altaistic Conference. 7-11 June 1976 / Ed. by Juha Janhunen. Helsinki : SuomalaisUgrilainen Seura. 259 p. P. 139-142.

Дата поступления: 26.06.2018 2.

\section{REFERENCE}

Borgoyakov, M. I. (1970) K voprosu ob etimologii gidronima «Molochnyi» [On the issue of the etymology of a hydronym "Molochnyj"]. Sovetskaya tyurkologiya, no. 5, pp. 85-87. (In Russ.). 
Borgoyakov, M. I. (1973) O proiskhozhdenii nazvaniya Sora [On the origin of the name of Sora]. In: Uchenye zapiski Hakasskogo nauchno-issledovatel'skogo instituta yazyka, literatury $i$ istorii. Abakan, Hakasskaya oblastnaya tipografiya. Vol. XVIII, pp. 142-144. (In Russ.).

Butanaev, V. Ya. (1995) Toponimicheskii slovar' Hakassko-Minusinskogo kraya [A toponymic dictionary of the Khakass and Minusinsk region]. Abakan, Hakasskii gosuniversitet im. N. F. Katanova. 268 p. (In Russ.).

Butanaev, V. Ya.(1999) Hakassko-russkii ehtnograficheskii slovar' [A Khakass-Russian ethnographic dictionary]. Abakan, Hakasskii gosuniversitet im. N. F. Katanova. 237 p. (In Russ.).

Burykin, A. A. (2011) Inoyazychnaya onomastika russkih dokumentov XVII-XIX vv., otnosyashchihsya k otkrytiyu i osvoeniyu Sibiri i Dal'nego Vostoka Rossii, kak istoricheskii istochnik [Foreign-language onomastics of the Russian documents of the 17-19th centuries related to opening and development of Siberia and the Far East of Russia as a historical source]: Diss.... Doctor of History. St. Petersburg. 476 p. (In Russ.).

Vinogradov, A. V. (2017) Gidronimy na mifologicheskoi osnove [Hydronyms on a mythological basis]. Nauchnoe obozrenie. Biologicheskie nauki, no. 3, pp. 14-36. (In Russ.).

Dambuev, I. A. (2017) Toponimicheskoe var'irovanie i voprosy normalizacii toponimov $\mathrm{v}$ Respublike Hakasiya [Toponymic variation and questions of normalization of toponyms in the Republic of Khakassia]. Yazyk i kul'tura, no. 38, pp. 23-40. (In Russ.).

Dul'zon, A. P. (1959) Tyurki Chulyma i ih otnoshenie k hakasam [Turkic peoples of Chulym and their attitude towards the Khakass]. In: Uchenye zapiski Hakasskogo nauchno-issledovatel'skogo instituta yazyka, literatury i istorii. Abakan, Hakasskoe knizhnoe izdatel'stvo. Vol. VII, pp. 93-102. (In Russ.).

Dul'zon, A. P. (1971) Etnolingvisticheskaya differentsiatsiya tyurkov Sibiri [Ethnolinguistic differentiation of Turkic peoples of Siberia]. In: Struktura i istoriya tyurkskih yazykov [The structure and history of Turkic languages] / ed. by E.V. Sevortyan. Moscow, Nauka. 311 p. Pp. 198-208. (In Russ.).

Dybo, A. V. (2017) Ob etimologicheskih parallelyah v grammatike altaiskih yazykov [On etymological parallels in the grammar of the Altai languages]. In: Mezhdunarodnyi forum «Altaiskaya tsivilizatsiya i rodstvennye narody altaiskoi yazykovoi sem'i» [Altai civilization and related peoples of the Altai family of languages: An international forum]: sb. vystuplenii i statei, posvyashchennyh istorii narodov, imeyushchih obshchie altaiskie istoriko-kul'turnye i ehtnogeneticheskie korni (Bishkek, Cholpon-Ata, 20-22 iyulya 2017 g.) / ed. by K. Moldokasymov. Bishkek, Turar. 992 p. Pp. 751-761. (In Russ.).

Kichikova, N. A., Mandzhieva, Eh. B. and Suprun, V. I. (2017) Toponimicheskii slovar' Respubliki Kalmykiya [Toponymic dictionary of the Republic of Kalmykia]. Ehlista, ZAOr «NPP «Dzhangar». 272 p. (In Russ.). 
Kyzlasov, L. R. (1959) K voprosu ob ehtnogeneze hakasov [To a question of ethnogenesis of Khakass]. In: Uchenye zapiski Hakasskogo nauchno-issledovatel'skogo instituta yazyka, literatury i istorii. Abakan, Hakasskoe knizhnoe izdatel'stvo. Vol. VII, pp. 70-92. (In Russ.).

Matveev, A. K. (1989) Finno-ugro-samodiiskaya toponimiya na territorii SSSR kak obyekt lingvisticheskogo issledovaniya [The Finno-Ugric-Samoyed toponymy in the territory of the USSR as an object of a linguistic research]. In: Voprosy finno-ugorskoi onomastiki [Issues of Finno-Ugric onomastics] / ed. by M. G. Atamanov. Izhevsk, Udmurtskii institut istorii, yazyka i literatury UrO AN SSSR. 182 p. Pp. 5-18. (In Russ.).

Matveev, A. K. (1995) Apellyativnye zaimstvovaniya i stratifikatsiya substratnykh toponimov [Appellative loans and stratification of sub-base toponyms]. Voprosy yazykoznaniya, no. 2, pp. 29-42. (In Russ.).

Matveev, A. K. (2008) Evolyutsionnye protsessy v onomastike [Evolutionary processes in onomastics]. Voprosy onomastiki, no. 6, pp. 130-136. (In Russ.).

Molchanova, O. T. (1979) Toponimicheskii slovar' Gornogo Altaya [A Toponymical dictionary of Mountain Altai]. Gorno-Altaisk, Gorno-Altaiskoe otdelenie Altaiskogo knizhnogo izdatel'stva. 397 p. (In Russ.).

Mongush, A. A. (2016) O geologicheskom znachenii nekotoryh toponimov Tuvy [About geological value of some toponyms of Tuva]. The New Research of Tuva, no. 1 [online] Available at: https://nit.tuva.asia/nit/article/view/72 (access date: 16.05.2018). (In Russ.).

Murzaev, Eh. M. (1996) Tyurkskie geograficheskie nazvaniya [Turkic place names]. Moscow, Izdatel'stvo Vostochnoi literatury. 253 p. (In Russ.).

Ondar, B. K. (1995) Kratkii slovar' gidronimov Tuvy [A Short dictionary of hydronyms of Tuva] / ed. by I. V. Kormushin. Kyzyl, Tuvinskoe knizhnoe izdatel'stvo. 48 p. (In Russ.).

Ondar, B. K. (2004) Toponimicheskii slovar' Tuvy [A Toponymical dictionary of Tuva]. Abakan, Izdatel'stvo HGU im. N. F. Katanova. 256 p. (In Russ.).

Osnovy finno-ugorskogo yazykoznaniya [Fundamentals of Finno-Ugric linguistics] (1974) / ed. by V. I. Lytkin. Moscow, Nauka. 484 p. (In Russ.).

Rozen, M. F. and Maloletko, A. M. (1986) Geograficheskie terminy Zapadnoi Sibiri [Geographical terms of Western Siberia]. Tomsk, Izdatel'stvo Tomskogo universiteta. 205 p. (In Russ.).

Sunchugashev, R. D. (2005) Hakasskie gidrograficheskie terminy [Khakass hydrographic terms]. In: Uchenye zapiski Hakasskogo nauchno-issledovatel'skogo instituta yazyka, literatury i istorii. Abakan, Hakasskoe knizhnoe izdatel'stvo. Vol. XXII, pp. 172-176. (In Russ.). 
Sunchugashev, R. D. (2009) Toponimiya Hakasii [Toponymy of Khakassia] / ed. by I. V. Kormushin. Abakan, Hakasskoe knizhnoe izdatel'stvo. 198 p. (In Russ.).

Tatarincev, B. I. (1976) Mongol'skoe yazykovoe vliyanie na tuvinskuyu leksiku [Mongolian language influence on the Tuva lexicon]. Kyzyl, Tuvinskii nauchnoissledovatel'skii institut yazyka, literatury i istorii. 129 p. (In Russ.).

Tatarincev, B. I. (1993) O nekotoryh drevnih toponimah tyurkskogo proiskhozhdeniya na territorii Tuvy [On some ancient toponyms of Turkic origin in the territory of Tuva]. In: Voprosy tuvinskogo yazykoznaniya [Questions of Tuvan linguistics] / ed. by D. A. Mongush and B. I. Tatarincev. Kyzyl, Tuvinskii nauchnoissledovatel'skii institut yazyka, literatury i istorii. 128 p. Pp. 105-112. (In Russ.).

Helimskii, E. A. (1996) Ocherk istorii samodiiskih narodov [Sketch of history of the Samoyed people]. In: Finno-ugorskii mir (Spravochnik po istorii, kul'ture i yazyku) [The Finno-Ugric world: A compendium on history, culture and language] / ed. by. Gyorgy Nanovski. Budapest, Veszpremi. 192 p. Pp. 101-115. (In Russ.).

Cheremisina, M. I. (1992) Yazyki korennyh narodov Sibiri [Languages of indigenous people of Siberia]: textbook. Novosibirsk, Novosibirskii gosudarstvennyj universitet. 92 p. (In Russ.).

Songmoo, Kho (1977) On the contacts between Korean and the Turkic languages. In: Altaica: Proceeding of the 19th Annual Meeting of the Permanent International Altaistic Conference. 7-11 June 1976 / Ed. by Juha Janhunen. Helsinki, SuomalaisUgrilainen Seura. 259 p. Pp. 139-142.

Submission date: 26.06 .2018$.

\section{Для цитирования:}

Каксин А. Д. Гидронимы Тувы: тюркские, монгольские, самодийские [Электронный ресурс] // Новые исследования Тувы. 2018, № 3. URL: https://nit.tuva.asia/nit/ article/view/789 (дата обращения: дд.мм.гг.). DOI: 10.25178/nit.2018.3.5

\section{For citation:}

Kaksin A. D. Water-names of Tuva: turkic, mongolian, samoyed. The New Research of Tuva, 2018, no. 3 [on-line] Available at: https://nit.tuva.asia/nit/article/view/789 (accessed: ...). DOI: 10.25178/nit.2018.3.5 